NBER WORKING PAPER SERIES

\title{
UNPRECEDENTED ACTIONS: \\ THE FEDERAL RESERVE'S RESPONSE TO THE GLOBAL FINANCIAL CRISIS \\ IN HISTORICAL PERSPECTIVE
}

Frederic S. Mishkin

Eugene N. White

Working Paper 20737

http://www.nber.org/papers/w20737

\author{
NATIONAL BUREAU OF ECONOMIC RESEARCH \\ 1050 Massachusetts Avenue \\ Cambridge, MA 02138 \\ December 2014
}

Presented originally at the conference, "The Federal Reserve System's Role in the Global Economy: An Historical Perspective" at the Federal Reserve Bank of Dallas, September 18-19, 2014. We particularly want to thank Michael Bordo and Steven Kamin for their helpful comments. We are also grateful for suggestions made by participants at the conference, the Columbia University Macroeconomics workshop and the Banque de France. The views expressed here are our own and are not necessarily those of Columbia University, Rutgers University, or the National Bureau of Economic Research. Disclosure of outside compensated activities for Mishkin can be found at http://www0.gsb.columbia.edu/faculty/fmishkin/

At least one co-author has disclosed a financial relationship of potential relevance for this research. Further information is available online at http://www.nber.org/papers/w20737.ack

NBER working papers are circulated for discussion and comment purposes. They have not been peerreviewed or been subject to the review by the NBER Board of Directors that accompanies official NBER publications.

(C) 2014 by Frederic S. Mishkin and Eugene N. White. All rights reserved. Short sections of text, not to exceed two paragraphs, may be quoted without explicit permission provided that full credit, including (C) notice, is given to the source. 
Unprecedented Actions: The Federal Reserve's Response to the Global Financial Crisis in Historical Perspective

Frederic S. Mishkin and Eugene N. White

NBER Working Paper No. 20737

December 2014

JEL No. E58,G01,N10,N20

\begin{abstract}
$\underline{\text { ABSTRACT }}$
Interventions by the Federal Reserve during the financial crisis of 2007-2009 were generally viewed as unprecedented and in violation of the rules - notably Bagehot's rule - that a central bank should follow to avoid the time-inconsistency problem and moral hazard. Reviewing the evidence for central banks' crisis management in the U.S., the U.K. and France from the late nineteenth century to the end of the twentieth century, we find that there were precedents for all of the unusual actions taken by the Fed. When these were successful interventions, they followed contingent and target rules that permitted pre-emptive actions to forestall worse crises but were combined with measures to mitigate moral hazard.
\end{abstract}

Frederic S. Mishkin

Columbia University

Graduate School of Business

Uris Hall 817

3022 Broadway

New York, NY 10027

and NBER

fsm3@columbia.edu

Eugene N. White

Department of Economics

Rutgers University

75 Hamilton Street

New Brunswick, NJ 08901-1248

and NBER

white@economics.rutgers.edu 
In response to the Great Inflation, governments were more willing to cede greater independence to central banks, giving them better specified mandates; and central banks were more willing to pledge adherence to rules and transparency; with both, apparently, limiting discretionary intervention. ${ }^{1}$ The resulting Great Moderation was thus, in large part, seen as a triumph of rules over discretion; and a recognition by policy makers of the time consistency problem. The success of reducing and stabilizing the inflation rate produced a consensus on the appropriate role and mandate for central banks (Mishkin, 2011). The global financial crisis that started in August 2007 and the disruptions of the subsequent seven years upset this consensus, and seemingly novel and unprecedented interventions were employed to address the panic and then revive markets and economies.

These "unprecedented" interventions included monetary policy easing at a time of robust growth and rising inflation, bailouts, new lending facilities, nonconventional monetary policy, such as quantitative easing, and large-scale international swap arrangements. By April 2008, these developments provoked former Fed Chairman Paul Volcker to comment that the Federal Reserve had "taken actions that extend to the very edge of its lawful and implied powers, transcending certain long-embedded central banking principles and practices." ${ }^{2}$ Solemn warnings have been issued about the perils of deviating from the mandates and rules that emerged out of the Great Moderation. Meltzer (2009) and Taylor (2009), for example, criticized the Fed for veering away from a clear and simple lender of last resort (LOLR) policy rule, as prescribed by Bagehot (1873) and other nineteenth century authorities, where it is clearly announced that financial institutions will not be bailed out. On the other hand, others like Madigan (2009) have asserted that the Fed's actions were in line with Bagehot's prescriptions.

In this paper, we provide a historical framework to evaluate the "unprecedented" actions of the Fed, comparing its actions to central bank responses to crises in the nineteenth and twentieth century. This exercise reveals that there is less novelty in the Federal Reserve's recent actions and that central banks over the last hundred and fifty years have often not followed the simple LOLR policy rule. Historical exploration of actual LOLR practices provides a context for deciding whether the Federal Reserve’s deviation from a Bagehot rule was appropriate.

\footnotetext{
${ }_{1}^{1}$ See for example, Bernanke et. al, (1999), Mishkin and Schmidt-Hebbel, (2002).

${ }^{2}$ As quoted in Coy (2008).
} 
Our review of leading financial crises in Britain, France and the United States, from the Overend-Gurney panic of 1866 to the collapse of LTCM in 1998, documents that "unprecedented" actions by central banks are the norm rather than the exception. The reason for this observation lies in the necessity of reconciling central banks' mandates for price stability and financial stability. Under fixed and flexible exchanges rate regimes, there are important benefits from a price-stability rule that can be easily monitored so that central banks, and the political authorities who delegate policy responsibility to them, will be induced to follow credible policies that avoid time-inconsistency problems. The nature of financial crises, however, is such that addressing them almost invariably requires a a temporary violation of rules, or the adoption of more flexible, less easily monitored, rules. Attempts to set a policy rule for financial stability by following Bagehot's recommendations accepts that policy will not seek to forestall a crisis but only respond when a financial crisis has hit, taking remedial action to assist solvent institutions but allowing the shock from the crisis percolates through the whole economy. However, in most episodes, central banks have acted pre-emptively to manage failures of large financial institutions and buffer the economy from the shocks emanating from the crisis. While the reactive approach risks a recession or a deeper recession, the pre-emptive approach creates incentives for moral hazard. For the latter approach to be successful, two elements are essential. First, the conditions when a rule may be temporarily violated must be well-understood so that it becomes a contingent rule and there will be no market penalty. Alternatively, a more flexible, less easily monitored, rule must make the central bank sufficiently accountable so that it constrains discretion and avoids the time-inconsistency problem. Secondly, in order to ensure that the pre-emptive approach does not set the stage for the next crisis, actions must be taken to mitigate moral hazard.

\section{Instrument, Contingent and Target Rules for Central Banks}

The problem of setting a proper mandate for a central bank dates to their very origin. Central banks became a common feature of sovereign nations in the nineteenth century, although there were precursors, notably the Bank of England and the Riksbank. They evolved as 
governments grappled with the problem of how to provide price stability and financial stability for their economies. ${ }^{3}$

To understand how governments provided mandates to their central banks, we need to be very clear about three different types of rules that central banks have followed: instrument rules, contingent rules, and target rules. For an instrument rule, a central bank agrees to set a policy instrument either to a particular value or to values that depend on states of the economy that are easily verified. The classic instrument rule is a metallic standard, where monitoring is managed by ascertaining the gold or silver content of coins. Nations employed metallic standards that converged towards the gold standard, which provided a monetary anchor, ensuring long but not short-term price stability. However, for transactions, a coin-only regime proved very costly and banks became the issuers of currency and deposits. Governments also directly issued currency, and this often led to abandonment of metallic-standard, instrument rules, resulting in to high- and hyper-inflations, a manifestation of the time-inconsistency problem of Kydland and Prescott (1977) and Calvo (1978) arising from the temptation to exploit seigniorage. This problem illustrated the need to delegate the responsibility for money creation to independent agencies. The standard origin of a nineteenth century central bank was as a privileged governmentchartered joint stock firm, privately owned, with clearly specified instrument rules for money creation that were easy to monitor by transparency rules and/or the appointment of some of its officials by the government (Grossman, 2010). Control of these banks was also exercised by the limited duration of their charter. For the premiere central banks, the Bank of England and the Banque de France, their charters were for fixed periods, well over a decade---to minimize shortterm political interference. Upon expiration, their charters were subject to modification prior to renewal by Parliament. ${ }^{4}$

The key, simple point here is that central banks were agents delegated by the legislature to conduct policy. To ensure that central banks avoided the time-inconsistency problem, they were expected to follow instrument rules that limited excessive money creation. Although instrument rules have the advantage that they are easily verified, they have the disadvantage that they can be too rigid, either because the evolution of the financial markets alter the structure of

\footnotetext{
${ }^{3}$ For a recent survey of the evolution of banking and central banking see Grossman (2010).

${ }^{4}$ Although Canada did not have a central bank, its decennial bank act of the nineteenth century served a similar purpose; and American national banks had finite charters until the McFadden Act of 1927.
} 
the economy or because of unforeseen events. ${ }^{5}$ In either case, instrument rules can then result in very poor and sometimes even disastrous economic performance. This problem with instrument rules points to the difficulty that the principal has in writing a contract for the agent that will cover all contingencies. The legislative process is often slow; unable to respond quickly to a financial crisis. Consequently, in certain circumstances escape clauses or practices, permitting the violation of the rules for price stability have been engineered, yielding the second type of rule, contingent rules. Contingent rules allow departures from the instrument rule in which discretionary policy is allowed in extraordinary circumstances. Bordo and Kydland (1995) have argued that the gold standard functioned as a contingent rule in the nineteenth century. ${ }^{6}$ Permitting its suspension in times of war or financial crisis gave the monetary authorities (provided they were not responsible for the crisis) with flexibility to cushion to the shock to the economy. ${ }^{7}$ This use of discretion did not necessarily result in the market imposing a penalty on the violating country, such as a higher risk premium for its sovereign bonds, as long as discretion was constrained by a transparent commitment to return to the instrument rule when conditions returned to normal.

Another alternative to instrument rules are target rules, which in the history of central banking represent an evolution, requiring increased trust as they cannot be monitored over the short-run as instrument rules can . A target rule makes the policymaker accountable to achieve a certain objective, say an inflation target. Target rules have the advantage over instrument rules that they can respond to unforeseen shocks or changes in the structure of the economy.

\footnotetext{
${ }^{5}$ A striking, modern example of the failure of an instrument rule as a result of a change in the structure of the economy is the failure of the Swiss monetary targeting rule in the 1980s. In 1975, the Swiss National Bank (SNB) announced a growth target for the monetary aggregate M1. Beginning in 1980, the SNB switched the money growth target to an even narrower monetary aggregate, the monetary base. Although monetary targeting was quite successful in controlling inflation in Switzerland for many years, it ran into serious problems with the introduction of a new interbank payment system, the Swiss Interbank Clearing (SIC), and a wide-ranging revision of the commercial banks' liquidity requirements in 1988. These structural changes caused a severe drop in banks' desired holdings of deposits, which were the major component of the monetary base, at the Swiss National Bank. A smaller amount of the monetary base was now needed relative to aggregate spending, altering the relationship between the two, and so the $2 \%$ target growth rate for the monetary base was far too expansionary. Inflation subsequently rose to over 5\%, well above that of other European countries. These problems with monetary targeting led the Swiss to abandon it in the 1990s and adopt a much more flexible framework for the conduct of monetary policy. For a detailed discussion of this episode, see Bernanke, Laubach, Mishkin and Posen (1999).

${ }^{6}$ In the literature on sovereign debt, "excusable defaults" represent a similar phenomenon (Grossman and van Huyck, 1988).

${ }^{7}$ Adherence to the gold standard was rarely a mechanical process and central banks often responded to domestic economic objectives (such as interest rate smoothing) in addition to movements in gold reserves (See Bordo, 1986; Eschweiler and Bordo, 1994, Dutton, 1984, Pippenger, 1984 and Giovannini, 1986). However, these actions were subordinated to the dominant commitment to keep the exchange rate within the gold points.
} 
However, target rules have the disadvantage over instrument rules in that they are less easy to verify because there are lags from the policy instruments to the objective. For example, monetary policy affects inflation with long lags, so inflation targeting central banks typically commit to achieving their targets over the immediate horizon, say two years. This medium-term horizon for the target means that verification of the success of policies today will not come until two or so years in the future. Target rules may also have elements of contingent rules and be quite flexible. Inflation targeting as practiced is often described as "flexible inflation targteting" (Bernanke, Laubach, Mishkin and Posen, 1999), and allows for short-run deviations from the target depending on the state of the economy. The flexibility and greater difficulty for verification of target rules has led critics of target rules to argue that they allow policymakers too much discretion. However, Bernanke and Mishkin (1997) argue that this criticism of target rules is misplaced. Rather, they see target rules, if they are sufficiently transparent (as is inflation targeting), as "constrained discretion". In other words, a transparent, target rule can constrain central banks from systematically engaging in policies with undesirable long-run consequences, thereby avoiding the time-inconsistency problem. However, target rules allow central banks some discretion for dealing with unforeseen or unusual circumstances.

For the Bank of England, the Act of 1844 or Peel's Act set the instrument rules under which it would operate. The law set the total fiduciary issue of banknotes that could be backed by securities at $£ 14$ million; any issue above this required $100 \%$ backing with specie. A rush for liquidity by financial institutions, discounting notes at the Bank of England, sometimes threatened a violation of the law; and the Treasury could offer the Bank "chancellor's letter" that would guarantee to indemnify the bank and secure any needed legislation to protect the Bank (Wood, 2005; Giannini, 2011). During the panics in 1847, 1857 and 1866, the Banking Act of 1844 was effectively suspended, relieving the specie constraint on the Bank of England's discretionary issue of currency. Understood to be only for the duration of the crisis, these exceptions "did no damage to convertibility commitment.",

As was recognized at the time, the problem is, of course, defining what constitutes and emergency. Perhaps, the most notable example of a suspension of an instrument rule during the gold standard was Great Britain’s suspension of convertibility from 1797 to 1821. In response to

\footnotetext{
${ }^{8}$ Bordo and Kydland, 1995, p. 431. These authors provide a table for 21 countries covering the period of the classical and interwar gold standards that documents to clearly defined circumstances when suspension of the gold standard was credibly consistent with the exchange rate regime.
} 
the threat of a French invasion, Great Britain shifted to a non-convertible paper pound that permitted inflationary finance. This long, temporary suspension lasted for the remainder of the Napoleonic wars, until a postwar deflation returned the pound to its prewar gold parity. Believed to be following a contingent rule, the government was allowed by the market to borrow at very low nominal rates in the inflationary environment that were consistent with a credible government promise to eventually return the pound to its prewar parity (Bordo and White, 1994).

Too rigidly adhering to an instrument rule may impose huge costs. For example, it might be argued that during the Great Depression of the 1930s the Federal Reserve interpreted its mandate too narrowly by failing to respond adequately to the financial crisis and thereby contributing to the depression. To ensure that the Fed had greater flexibility, in the aftermath of the economic collapse, Congress put Section 13(3) into the Federal Reserve Act that permitted the Fed to use discretion to provide credit beyond its usually constrained limits in "unusual and exigent circumstances.”

A vital question facing central banks today is how to combine the mandates for price stability and financial stability. In times of crisis, a target rule with "constrained discretion" may be superior to an instrument rule by permitting temporary deviations to accommodate certain types of shocks that both policy makers and the market understand to be exceptional. The historical evidence suggests that it is possible to design target and contingent rules that overcome the potential for moral hazard that is inherent in permitting some discretionary authority. In this paper, we detail several important crises that illustrate the benefits of following a target or contingent rule, provided that discretionary policy interventions are followed by actions that substantially reduce the moral hazard that follows from such interventions. To frame our discussion, we begin by identifying the generally accepted "unprecedented” actions that the Fed took in response to the Crisis of 2008 that violate the policy rule advocated by Thornton, Bagehot and strictly interpreted by their modern adherents. Then, we compare them to actions taken by the monetary authorities in previous crises. The monetary authorities are considered very broadly to include not only the central bank but also the Treasury and any central bank substitutes, including clearing houses. . 


\section{The Fed's Unprecedented Actions in the Recent Financial Crisis}

There were seven actions that were considered extraordinary or unprecedented in the recent crisis:

1. Unusually Easy Monetary Policy. The first glimmers of the global financial crisis appeared on August 9, 2007, when BNP Paribas announced that it had suspended redemptions on three of their funds, indicating that they were unable to value the collateralized debt obligations (CDOs) held by these funds because of an evaporation of liquidity for the underlying subprime mortgage assets. As a result, lending in the interbank markets seized up, with the spread between the Libor rate and the overnight index swap (OIS) rate shooting up from under 10 to over 100 basis points in the next several of weeks. In response, the Fed lowered the spread between discount rate and the federal funds rate target by 50 basis points on August 17. Then, at its September 18 meeting, the FOMC cut the federal funds rate target by 50 basis points. What was unusual was that monetary policy eased while the momentum in the economy was quite strong, with real GDP growing at nearly 3\% and inflation rising. By the time that the recession began in December of 2007, the Fed had lowered the federal funds rate target by 100 basis points, reducing it further by May 2008 for a total decline of 325 basis points, even though the CPI did not peak at nearly 6\% until July of 2008. These actions well in advance of panic the arising from Lehman Brothers collapse in September of 2008 emphasize the pre-emptive character of monetary policy.

2. New Non-Bagehot Liquidity Facilities. During the global financial crisis, the Federal Reserve created a number of new credit facilities that provided liquidity, but not at high interest rates as proposed by Walter Bagehot. Although the discount rate was further reduced so that it was only 25 basis points above the federal funds target in March 2008, borrowing from the discount window did not to appear to provide sufficient liquidity. Discount window borrowing had a "stigma" because it suggested that a borrowing bank might be desperate for funds and thus be in trouble. To encourage additional borrowing, the Fed set up a temporary Term Auction Facility (TAF) in December 2007 to auction Fed funds. The TAF facility became more widely used than the discount window because it avoided the stigma problem and enabled banks to borrow at a competitive rate lower than the discount rate. The TAF auctions started at $\$ 20$ billion and rose as the crisis worsened to over $\$ 400$ billion. The Fed further broadened its provision of 
liquidity to the financial system, well beyond its traditional lending to banking institutions, by creating lending facilities for investment banks in March 2008 (the Term Securities Lending Facility--TSLF, Primary Dealer Credit Facility--PDCF), as well as lending facilities to promote purchases of commercial paper, mortgage backed-securities, other asset-backed securities and money-market-mutual fund assets after the collapse of Lehman Brothers in September of 2008 (Asset-Backed Commercial Paper Money Market Mutual Fund Liquidity Facility--AMLF, Commercial Paper Funding Facility--CPFF, Money Market Investor Funding Facility--MMIFF, Term Asset-Backed Securities Loan Facility--TALF). The enlargement of the Fed's lending programs during the 2007-2009 financial crisis was remarkable, reaching a peak of over \$1.5 trillion dollars by the end of 2008 .

3. International Central Bank Cooperation. The Fed also became an international lender of last resort to central banks during the crisis. In December 2007, the Fed set up swap lines for the European Central Bank and the Swiss National bank to allow them to borrow dollars from the Fed so that they could make dollar loans to their domestic banks. After the Lehman Brothers collapse, the Fed arranged swap lines with the central banks of Japan, the U.K., Canada, Australia, Sweden, Norway, Denmark, New Zealand, Mexico, Brazil, Korea and Singapore. At its peak in December of 2008, the Fed had extended almost $\$ 600$ billion of these swaps to foreign central banks.

(4) Non-Conventional Monetary Policy. In the last few decades, the Fed's open market operations normally involved only the purchase of short-term government securities. However, during this crisis, the Fed saw a need to adopt a nonconventional monetary policy of large-scale asset purchases (LSAPs) to lower interest rates for particular types of credit. To support the mortgage-backed securities market (MBS) and lower interest rates on residential mortgages, the Fed set up a Government Sponsored Entities Purchase Program in November 2008, through which the Fed eventually purchased $\$ 1.25$ trillion of MBS guaranteed by Fannie Mae and Freddie Mac. This program was dubbed quantitative easing (later becoming QE1) because it resulted in a large increase in the Fed's balance sheet and the monetary base. However, as argued by former Chairman Bernanke, this program was directed not at expanding the Fed's balance sheet, but at improving the function of particular credit markets, hence he referred to the program as credit easing, rather than quantitative easing. By the time that financial markets recovered, the federal funds rate was effectively at zero. To further pursue an expansionary 
policy and revive the economy, the Fed announced in November 2010 that it would purchase $\$ 600$ billion of long-term Treasury securities at a rate of about $\$ 75$ billion per month. This largescale purchase program, which became known as QE2, was intended to lower long-term interest rates. In September 2012, the Federal Reserve announced a third large-scale asset-purchase program, QE3, which combined elements of QE1 and QE2 by conducting purchases of \$40 billion of mortgage-backed securities and \$45 billion of long-term Treasuries. However, QE3 differed from the previous QE programs in that it was not for a fixed dollar amount, but was instead open-ended, with the purchases continuing "if the outlook for the labor market does not improve substantially.” Starting in December of 2013, the Fed announced that this program would be phased out gradually over time.

5. Central Bank Rescues of Financial Institutions/Provision for Orderly Liquidations. In early March of 2008, short-term financing for the investment bank, Bear Stearns, dried up because of a run on the shadow banking system (Gorton and Metrick, 2009). Uncertain of the value of the collateral backing Bear Stearns repurchase agreements, the market would not roll over these loans. Because the value of Bear Stearns' long-term assets would plummet if quickly sold, the firm faced imminent failure. The Fed worried that the failure of Bear Stearns might trigger a full-fledge financial crisis, so it brokered a deal for JP Morgan/Chase to purchase Bear Stearns, with the Fed, taking $\$ 30$ billion of Bear Stearns’ toxic assets on to its books. ${ }^{9}$ The Fed arranged a bailout because JP Morgan was unwilling to take these hard-to-value assets onto its books. Then, on Monday, September 15, 2008, after suffering losses in the subprime market, Lehman Brothers filed for bankruptcy - the largest bankruptcy filing in U.S. history---as the Fed stood aside. Officials at the Federal Reserve and the U.S. Treasury have argued that they did not have the legal resolution authority to intervene to prevent a Lehman bankruptcy. On the other hand, given the extraordinary efforts the Federal Reserve made to bail out Bear Stearns, it seems plausible that the Fed and the Treasury made a conscious decision not to bail out Lehman Brothers. $^{10}$ The Fed's safety net was soon extended to insurance companies. The Financial Products Unit of American International Group (AIG) had written over \$400 billion dollars of

\footnotetext{
${ }^{9}$ Legally, the Fed could not purchase these assets directly. Instead, it in effect acquired them by making a nonrecourse loan to JP Morgan, where the Fed could not require the bank to pay back the loan and so took ownership of the toxic collateral, which ended being worth less than what the Fed paid.

${ }^{10}$ Many commentators have argued that allowing Lehmann to go bankrupt was a colossal mistake that turned a mild financial disruption into a global financial crisis, but there was a plausible case for letting Lehman go into bankruptcy, as argued in Mishkin (2011).
} 
credit default swaps, which after Lehman Brothers’ collapse, left it facing enormous payments. Observing these potential losses, the market refused to continue short-term funding to AIG. In response, on September 16, 2008, the Fed stepped in with an \$85 billion loan to keep AIG afloat. $^{11}$

6. Treasury Collaboration/Intervention/Aid. When the financial crisis entered a particularly virulent phase after the collapse of Lehman Brothers (Mishkin, 2010), further assistance to failing financial institutions was viewed as urgent. After a messy fight in Congress, the Bush Administration’s Economic Recovery Act of 2008 was passed on October 3, 2008, creating the Troubled Asset Relief Plan (TARP). This program initially intended to purchase subprime mortgage assets to prop up financial institutions' balance sheets. However, it soon became clear that agreeing on prices for assets was impossible. The Treasury then switched to using the TARP funds to inject capital into financial institutions, thereby shoring up their balance sheets directly. In addition, on September 29, the U.S. Treasury had announced a Temporary Guarantee Program for Money Market Funds, which insured that MMMFs would not "break the buck” and investors would receive at least the \$1 par value per share. Subsequently, on October 14, 2008, the FDIC announced the Temporary Liquidity Guarantee Program (TLGP) that guaranteed newly-issued senior unsecured bank debt, such as federal funds and commercial paper, as well as noninterest bearing transaction accounts. Its stated purpose was to "strengthen confidence and encourage liquidity in the banking system” (FDIC, 2008). Although the Federal Reserve was not directly involved in administering these programs, they were part of a package of bailouts of financial institutions, and the Federal Reserve lobbied Congress to implement these programs.

7. Supervisory Actions. Concerned about public confidence in the solvency and viability of the leading financial institutions, the Treasury’s announced in February 2009 that the nineteen largest banking institutions would be placed in the Supervisory Capital Assessment Program (SCAP) that would administer stress tests led by the Federal Reserve in cooperation with the Office of the Comptroller of the Currency (OCC) and the FDIC. The initial stress test was designed as a forward-looking exercise to estimate the possible erosion of bank capital under two scenarios: the February 2009 baseline consensus forecast by private sector economists of a continuing decline in economic activity and a worst case scenario of a much more severe

\footnotetext{
${ }^{11}$ Total loans to AIG from the Fed and the U.S. government rose to over $\$ 170$ billion.
} 
recession (Board of Governors of the Federal Reserve System, 2009). The Treasury announced the results in early May 2009, which were well received by market participants. The stress test improved market confidence and encouraged the recapitalization of these banks and the stabilization of the financial system (Acharyal and Seru, 2013). ${ }^{12}$

To put these "unprecedented" actions during the Crisis of 2008 into a historical perspective, Table 1 divides them into seven categories, with with an " $\mathrm{X}$ " in the top row indicating that they were undertaken. In the following rows we present selected crises from the previous 150 years for comparison, which are accompanied by brief narratives explaining how and why exceptional or "rule-violating" actions were undertaken by the monetary authorities to quell the crisis.

\footnotetext{
${ }^{12}$ Hoshi and Kashyap (2010) found that similar stress tests in Japan in 2003 were a key element of the recovery of the Japanese banking system after the "lost decade" from 1992 to 2002.
} 
Table 1

Unprecedented Actions by Monetary Authorities in Financial Crises

\begin{tabular}{|c|c|c|c|c|c|c|c|}
\hline & $\begin{array}{l}\text { Unusual } \\
\text { Monetary } \\
\text { Easing }\end{array}$ & $\begin{array}{c}\text { Non- } \\
\text { Bagehot } \\
\text { Liquidity } \\
\text { Facilities }\end{array}$ & $\begin{array}{l}\text { International } \\
\text { Central } \\
\text { Bank } \\
\text { Cooperation }\end{array}$ & $\begin{array}{c}\text { Non- } \\
\text { Conventional } \\
\text { Monetary } \\
\text { Policy }\end{array}$ & $\begin{array}{c}\text { Rescue/ } \\
\text { Orderly } \\
\text { Liquidation } \\
\text { of } \\
\text { Financial } \\
\text { Institution }\end{array}$ & $\begin{array}{c}\text { Direct } \\
\text { Treasury } \\
\text { Collaboration/ } \\
\text { Intervention/ } \\
\text { Aid }\end{array}$ & Supervision \\
\hline & 1 & 2 & 3 & 4 & 5 & 6 & 7 \\
\hline $\begin{array}{l}\text { U.S. } \\
2008\end{array}$ & $\mathbf{X}$ & $\mathbf{X}$ & $\mathbf{X}$ & $\mathbf{X}$ & $\mathbf{X}$ & $\mathbf{X}$ & $\mathbf{X}$ \\
\hline $\begin{array}{l}\text { U.K. } \\
1866 \\
\end{array}$ & & & & & & $\mathbf{X}$ & \\
\hline $\begin{array}{c}\text { France } \\
1889\end{array}$ & & & & & $\mathbf{X}$ & $\mathbf{X}$ & \\
\hline $\begin{array}{l}\text { U.K. } \\
1890\end{array}$ & & & $\mathrm{X}$ & & $\mathbf{X}$ & $\mathbf{X}$ & \\
\hline $\begin{array}{l}\text { U.S. } \\
1907\end{array}$ & & $\mathbf{X}$ & $\mathbf{X}$ & & & $\mathbf{X}$ & \\
\hline $\begin{array}{l}\text { U.S. } \\
1929\end{array}$ & & $\mathbf{X}$ & & & & & \\
\hline $\begin{array}{c}\text { U.S. } \\
1930-1933\end{array}$ & & & & $\mathbf{X}$ & $\mathbf{X}$ & $\mathbf{X}$ & $\mathbf{X}$ \\
\hline $\begin{array}{c}\text { Penn Central } \\
1970\end{array}$ & & $\mathrm{X}$ & & & & & \\
\hline $\begin{array}{l}\text { Continental } \\
\text { Illinois 1984 }\end{array}$ & & & & & $\mathrm{X}$ & & \\
\hline $\begin{array}{c}\text { Crash of } \\
1987\end{array}$ & & $\mathbf{X}$ & & & & & \\
\hline $\begin{array}{c}\text { LTCM } \\
1998\end{array}$ & $\mathbf{X}$ & & & & $\mathbf{X}$ & & \\
\hline
\end{tabular}




\section{Bagehot's Rule and the Crises of 1866, 1889 and 1890}

Contemporary policy debates about how a LOLR should respond to a financial crisis are framed as much as by history as by theory. This history is largely informed by a "classical” view of how the Bank of England should check financial crises century. The progenitors of this view, Henry Thornton (1802) and Walter Bagehot (1873), argued that the Bank of England should react to a banking panic by lending freely through the discount window at a high rate of interest on all collateral that would be considered good in normal, non-crisis times, preventing illiquid but not insolvent banks from failing. ${ }^{13}$ This advice was predicated on the fact that Britain was on the gold standard and a high rate would protect the Bank of England's reserves, and thus a currency crisis following on the heels of a banking crisis (Grossman and Rockoff, 2014). It should also be remembered how the discount rate was supposed to be managed in ordinary, noncrisis times. Changes in the discount rate were supposed to follow the gold standard's "rules of the game," rising in response to a balance of payments deficit and reduced when there was a surplus. The objective was to speed up the operation of the gold standard's adjustment process and reduce the associated and costly gold flows. The discount rate then reacted to the balance of payments movements. The recommendation given by Bagehot to the Bank of England for crisis times complements the "rules" for ordinary times.

Humphrey (1975) and Bordo (1990) point out that according to the Thornton-Bagehot approach,it is not the duty of the LOLR to prevent financial shocks but neutralize them once they have occurred by halting the spread of a panic. The Thornton-Bagehot approach is a reactive policy, unlike the "unprecedented" actions that may be considered to be preemptive policies, but it has attractive characteristics, as the refusal to save insolvent institutions keeps moral hazard at bay and the high rate provides an automatic exit strategy, as banks quickly paid off loans from the bank. .

The Thornton-Bagehot approach does have elements of an instrument rule because it makes recommendations for how a policy instrument, the discount rate, should be set and how the discount facility should be administered. However, it is important to note that the ThorntonBagehot approach it is not nearly as precise and easily monitored as the gold standard or more

\footnotetext{
${ }^{13}$ Bagehot's explanation of how the Bank should act was partly a response to criticism that his proposed LOLR operations would bring upon moral hazard (Wood, 2005; Grossman, 2010, p. 91)
} 
modern instrument rules such as the Taylor rule or the monetarist constant-money-growth rate rule. For want of a better name, we refer to the Thornton-Bagehot approach as Bagehot's rule throughout the rest of this paper, keeping in mind that it is not quite as rigid as many instrument rules.

Reviewing the history of the Bank of England, Bagehot emphasized that the Bank, having the greatest reserves, could quell a panic by providing cash for good collateral at a rate sufficiently high to deter excessive use of the bank's facility. Although Bagehot's book was written after the Overend, Gurney, and Co. Panic of 1866, it has been recently documented (Bignon, Flandreau and Ugolini, 2012) that his prescription was put into effect after a crisis in 1847. In this panic, the Bank kept its discount rate below the market rate and rationed credit, exacerbating the crisis. The Bank of England's full adherence to Bagehot's rule was made plain in 1866 when the large Overend-Gurney bank was recognized to be insolvent and the Bank of England signaled that it had no intention of aiding the bank, precipitating a panic (Flandreau and Ugolini, 2014). When it was announced that Overend-Gurney had suspended, the bank rate was raised from 7 to 9 percent and then to 10 percent, well above the market rate for bills. Banks and bills brokers crowded the discount window at the Bank, but there was no decline in the quality accepted as collateral. Eventually, the panic abated. While the Bank's response to the 1866 panic is considered by many to be the correct response that can be announced ahead of time, thereby providing commitment, it should be noted that the Bank was only able to act as a LOLR because it had secured a “chancellor's letter” from the Treasury. The chancellor's letter promised indemnification, if needed, via a bill in Parliament. The letter from the Chancellor of the Exchequer permitted the Bank of England to violate the instrument, price-stability rule governing reserves for banknotes, set by the Bank Act of 1844. Overend-Gurney was thus an understood to be an emergency when the Bank could credibly violate the price stability rule in order to ensure financial stability, with the backing of the Treasury. Hence this application of Bagehot's rule was not a pure application of an instrument rule, but had elements of a contingent rule. As this action violated the price-stability, instrument rule, we classify the issuance of a chancellor's letter as an unconventional policy action, in terms of a gold standard regime, in Table 1.

While most economists and policy makers treat Bagehot and the Bank of England's behavior from the 1866 crisis to 1914 as the "gold standard" for a LOLR, both the Bank of 
England and the Banque de France---the two most important central banks of the era---deviated from this policy advice and engaged in what would be termed today as unprecedented policy actions that deviated from the gold standard instrument rule. ${ }^{14}$ First, in 1889, the Banque de France engineered a lifeboat operation to rescue one the largest Paris banks, and then in 1890, the Bank of England followed suit with a lifeboat for Barings Brothers à la française. These actions get little attention in the debate over the appropriate rules for a LOLR, but they were important steps in the evolution of central banking policy in response to the evolution of the financial system in the 1880s.

In 1882, a crash on the Paris stock market led to the collapse of Union Générale, one of France's largest banks and as well as several smaller banks. Defaulting counterparties in the forward market for stocks caused a crucial number of brokers to fail, threatening the solvency of the whole Paris Bourse. The brokers lacked the statutory collateral the Banque de France required for loans, but a consortium of banks, with the right collateral, stepped in as an intermediary, ensuring that the brokers had sufficient liquidity. Although the Banque de France also lent freely to the rest of the market, it refused to provide any assistance to the insolvent Union Générale, the Bourse in Lyon and other banks. (White, 2007). A long deep recession ensued that caused some in the Banque to question whether they had acted correctly. Thus, when a run on one of the largest banks, the Comptoir d'Escompte, began in 1889, the Banque lent freely at a rate, higher than the market rate, to all borrowers with good collateral; but it also saved the insolvent Comptoir (Hautcoeur, Riva, and White, 2014). This bank had supported an attempt to corner the copper market with large loans and massive guarantees of copper forward contracts. When the price of copper collapsed, the bank was insolvent. Pressed by the Minister of Finance who offered an early renewal of the Banque’s charter as an inducement, the Banque provided loans of 140 million francs against all the Comptoir's assets, good and bad---a violation of the strict, statutory, instrument rules governing collateral for lending. A guarantee syndicate of banks, whose membership was determined partly on ability to pay and partly on involvement in the copper speculation, was induced to cover any losses up to 40 million francs (Hautcoeur, Riva, and White, 2014). Some on the Banque de France’s Council of Regents were opposed to this unprecedented action, but credit to the Comptoir halted a run that appeared to presage a

\footnotetext{
${ }^{14}$ Grossman (2010) discusses some early examples of bailout in Australia (1826), Belgium (1839) and Germany (1848).
} 
general panic. The Banque then held the Comptoir's bad assets, permitting the copper market to recover and an orderly resolution to proceed through the courts. The buildings and accounts of the failed bank were transferred to its recapitalized successor. Severe financial penalties were meted out to the Comptoir's board of directors and others involved in the disaster, actions that appear to have been designed to mitigate moral hazard from this intervention. No other major financial crisis occurred in France until the outbreak of World War I. In Table 1, this 1889 crisis is tagged as having two "unprecedented" interventions---a bailout/resolution and Treasury intervention.

A year after the French crisis, in November 1890, one of the leading British banks, Baring Brothers was found to be on the brink of failure. Before a panic could take hold, the Bank of England took unprecedented pre-emptive actions (Clapham, 1945). Barings had originated and underwritten vast issues of Argentine securities. Having borrowed heavily and unable to sell off its portfolio of these bonds, as their value dropped, the bank approached the Bank of England. Alarmed that this leading house might be insolvent, the Bank informed the Treasury of the situation. In contrast to France in 1889, the initiative for action came from the central bank; and the British Treasury refused to countenance any direct support, even though the Chancellor of the Exchequer believed that, if Barings, went under the crisis would be far more severe than the Overend-Gurney Crisis of 1866. Following the example of 1866, he offered a "chancellor's letter," which have would permitted the Bank to increase its circulation beyond its legal limits. This offer was refused by the Governor of the Bank of England who apparently was afraid that news of this action might set off a panic.

However, the gold reserves of the Bank were threatened as institutions discounted with the Bank, presenting the possibility of a currency crisis in the globalized capital market of the period. To shore up its gold reserves, the Bank of England borrowed $£ 3$ million from the Banque de France, providing Treasury bills as collateral, which were obtained by selling consols to the Commissioners of the National Debt. The Governor explained to his French counterpart that although the Bank could induce gold to flow to England by raising the bank rate, such a measure "would have been too severe," alarming the City and he "preferred not to adopt the course usually taken.” (Clapham, 1945, Vol. 1, p. 330). In addition, £1.5 million was purchased from Russia by the sale of Exchequer bonds. Thus, the Bank recognized that following 
Bagehot's rule might signal a weakness that could bring about further bank runs or a run on the pound. Borrowing from foreign central banks and governments was preferable.

Meanwhile, it was quietly ascertained that Barings was probably insolvent. Sensing these problems, the Bank of England was flooded by requests to discount Barings paper (Clapham, 1945). Faced with accepting bad collateral, the Governor demanded that the Treasury provisionally guarantee loans to Barings to maintain its liquidity so that the Bank would have time to form a guarantee syndicate to absorb any potential losses. The Governor quickly assembled a syndicate of banks and other financial houses whose pledges totaled £17,105,000. This sum was more than sufficient to protect the Bank from losses, as its maximum advance was $£ 7,526,600$. The guarantee syndicate was set to last for three years, while the Bank "nursed" Barings' assets. However, this task was not completed and, over the protests of some syndicate members, it was renewed for another two years, with a reduction in the pledge to a quarter of the initial sum. Liquidation was finally completed in 1895; and although the funds of the syndicate were not drawn upon, the Barings family was compelled to cover losses with their private fortunes-a step to mitigate the moral hazard consequences of intervention. Although the Bank of England was generally praised for this action that pre-empted a panic, the Economist warned its readers that this was a dangerous precedent, describing the potential risk of moral hazard. In Table 2, the Barings episode includes three unusual actions: central bank cooperation, managing an insolvent institution, and Treasury cooperation with a promise of intervention if needed.

The unprecedented actions of 1889 and 1890 raise the obvious question why didn't the Banque de France and the Bank of England strictly follow Bagehot's rule or perhaps why didn't Thornton or Bagehot discuss the possibility of a lifeboat. The answer would seem to be that certainly in 1802 and even as late as 1873 the British financial system was not yet dominated by large leveraged institutions that were highly interconnected with other large institutions and the globalized financial markets of the late nineteenth century were just emerging. To use an anachronistic term, no "systemically important financial institutions" or "SIFIs" had emerged. The merger waves that ultimately produced a nationally concentrated industry were still in the future (Capie and Rodrik-Bali, 1982). While a panic could render many banks illiquid, Thornton and Bagehot saw individual banks' solvency questions as relatively unconnected. Two decades after Lombard Street was written, the financial industry presented a problem that the Banque de 
France and the Bank of England addressed by taking unprecedented actions beyond following Bagehot's rule.

\section{The Crisis of 1907}

Analyzing the Crisis of 1907 from the point of view of a LOLR is an awkward exercise as the United States did not, of course, have a central bank yet. The New York Clearing House (NYCH) might be categorized as a quasi-central bank because of its ability to add to interbank liquidity via the issue of clearinghouse loan certificates, but it was not a government-sponsored central bank and had no mandate for price stability. Nevertheless, it is useful to detail the interventions that were deployed in the U.S. by the NYCH and the Treasury and, in Europe. by the central banks.

Like the 1889 crisis in France, the panic of 1907 in the United States was set off by the failure of an attempted copper corner at the time when liquidity was particularly tight. In response to gold outflows from British insurance companies payments for the San Francisco earthquake of 1906 (Odell and Weidenmier, 2004), the Bank of England raised its discount rate and the Banque de France created a special facility to draw gold from the United States by paying interest on gold in transit to France. During the week of October 14, 1907, 5 members and 3 non-members sought assistance from the NYCH and were accommodated. But, when a run on the non-member Knickerbocker Trust began on October 21, it was denied assistance from the NYCH; and runs broke out against other trust companies. Secretary of the Treasury George Cortelyou tried provided some liquidity by depositing $\$ 25$ million in the major central reserve city banks on October 24 but with little effect (Friedman and Schwartz, 1963).

As credit dried up, interest rates shot up and stock prices fell. On the same day as the Treasury acted, J.P. Morgan persuaded the member banks of the NYCH to lend to a "money pool" to enable brokers on the New York Stock Exchange to complete a settlement. The rush for liquidity did not abate and on October $25^{\text {th }}$, the NYCH announced the issuance of clearing house loan certificates - an action that eased the demand for liquidity by increasing liquidity for interbank transactions---and the suspension of deposit convertibility (Moen and Tallman, 2000). As a consequence a premium on currency and coin arose, creating an incentive to import gold from abroad. 
The international dimension of 1907 is particularly important. Although the Bank of England has been referred to as the "conductor of the orchestra" of the globalized financial markets because London was world's largest financial center and changes in the Bank's discount rate usually led other central banks to follow suit, it was the Banque de France, with Paris as the second largest financial center, that had far greater gold reserves that provided assistance to other central banks. Thus, in the immediate aftermath of the American crisis in October, when the Bank of England's high discount rate did not end gold exports that were causing its reserves to shrink, the Banque de France announced on November 7 that it would purchase 80 million francs of sterling bills and forwarded 80 million francs of U.S. gold eagles to London to allay the drain. When gold outflows in France became acute, Banque of France announced on November 22 that it would create a special facility that eased liquidity both in France and the United States (Rodgers and Payne, 2014). The high premium on gold in New York led to an outflow of circulating gold in France. To allay this temporary, extraordinary demand, the Banque created a special loan facility where French bankers could discount commercial paper on very favorable terms to obtain U.S. gold eagles from the vaults of the Banque. Estimated to be 80 million francs or $\$ 16$ million, the eagles were then shipped to the U.S. in lieu of French coin that remained in circulation (Rodgers and Payne, 2014). In Table 1, the 1907 crisis had three unusual action: new liquidity facilities, central bank cooperation, and Treasury assistance.

In the United States, the failure of the NYCH to provide liquidity to Knickerbocker Trust to enable it to ride out the crisis or liquidate it in a more orderly fashion is central to the story of the panic's generation, although intervention would have required further actions to mitigate moral hazard. The severe panic and recession were, of course, what led to the creation of the Federal Reserve. Although established in 1913, the Fed did not become an independent central bank until it had finished assisting the Treasury with the financing of World War I. In the 1920s, the Fed fine-tuned its policy techniques, managing a period of low inflation and low unemployment, not unlike the Great Moderation. This period abruptly closed with multiple crises that yielded the Great Depression. Here we divide the crises of Great Depression into the Stock Market Crash of 1929, where the Federal Reserve acted appropriately as a LOLR, and the banking crises of 1930-1933, where the Fed failed as a central bank. 


\section{The Stock Market Crash of 1929}

The stock market boom and bust of 1928-1929 provided the first big test for the Federal Reserve. The October 1929 crash hit the largest market for short-term funds--brokers' loans. Banks, individuals, and companies with extra cash lent to brokers, who in turn lent on margin to investors. Panicked that investors might default on their margin loans from brokers, lenders to brokers withdrew their call loans and refused to renew their time loans, creating the possibility of broker bankruptcies and fire sales of collateral, with the effects spilling over to other markets. When the New York City banks stepped in to replace loans to brokers, supplying approximately \$1 billion, the Federal Reserve Bank of New York let it be known that "the discount window was wide open” for member banks. The discount rate remained low in violation of Bagehot's rule. The New York Fed also gave these banks additional reserves through open market purchases of $\$ 160$ million, ensuring that the crash was confined to the stock market and did not fuel a banking panic (Friedman and Schwartz, 1963, p. 339).

In the aftermath of the New York Fed's action, credit spreads declined to levels below those before the stock market crash (Mishkin, 1991). The low level of credit spreads up until October 1930 is remarkable given the sharp economic contraction up to that point and the over $40 \%$ decline in the value of common stocks. This phenomenon suggests that the unprecedented actions of the New York Fed were successful in containing the initial financial disruption.

However, the purchases of securities that the New York Fed made were in excess of those approved by the Open Market Investment Committee, an unprecedented action that departed from established, instrument-rule, operating procedures, angering the Board. In Table 1, this unusual monetary easing is indicated in Column 1 for 1929. New York's policy came to an end when the Board indicated its displeasure with the New York Fed for bailing out speculators and policy tightened. This stance was maintained by the Fed, even as as the economy slowed through 1930-1932 and three major banking panics swept through the financial system. The Fed reduced the discount rate but deflation kept real rates high and open market operations remained feeble. The Federal Reserve's inaction in these years is well-known and has been held largely responsible for the economic collapse. For this essay, what is striking is the absence of unprecedented actions by the Fed when banking panics began to occur, starting in the 
fall of 1930; and, indeed, innovative policy responses did not come from the Fed but from Republican and Democratic administrations working with Congress.

\section{The Banking Panics of 1930-1933}

The Federal Reserve's policy mistakes that contributed to the onset and duration of the Great Depression have been well documented. ${ }^{15}$ In accounts of the economic collapse, the failure of the Fed to act promptly and forcefully as a LOLR to halt and offset the four banking panics has played central role (Friedman and Schwartz, 1963; Romer, 1990). A variety of reasons for these mistakes have been offered: poor institutional design of the Fed, poor theory and interpretation of the effects of monetary actions, and the fear that the nation's ability to remain on the gold standard was imperiled (Bordo and Wheelock, 2014). From our vantage point, these factors all contributed to induce the Fed---especially, the Board and some Federal reserve banks--to adhere too strictly to the instrument rules laid down by the Federal Reserve Act presumably to ensure price stability and financial stability. Unlike its pre-1914 European counterparts and the New York Fed in 1929, the Fed undertook no "unprecedented" actions. Faced with crisis after crisis, the Fed maintained its very circumscribed mandate, while presidents and the Congress sought innovative interventions. However, trusting to the Fed, they did not act promptly and given the slow nature of the legislative process, which allowed special interests to exercise influence, the effectiveness of their actions varied considerably.

The limits on the central bank were engineered by the Federal Reserve Act of 1913 that created a decentralized central bank of twelve regional bank supervised by the Federal Reserve Board in Washington, D.C. Each of the Federal reserve banks was empowered to discount eligible paper for its member banks---national banks and state-chartered banks that opted to join. The reserve banks set their own discount rates subject to Board approval. ${ }^{16}$ The Fed focused on ensuring that only "real bills" were discounted, narrowly defining the type of collateral—eligible paper--that would be acceptable. ${ }^{17}$ Discounting member banks would receive Federal Reserve

\footnotetext{
${ }^{15}$ A short list seminal works would include Friedman and Schwartz (1963), Wicker (1966), Meltzer (2003), Wheelock (1991) and Bordo and Wheelock(2013).

${ }^{16}$ The discount rate declined somewhat as a policy tool and open market operations gained importance, being used to hit a borrowed reserves target.

${ }^{17}$ The Act permitted discounting of "notes, drafts, and bills of exchange arising out of actual commercial transactions." Discounting of loans for "the purpose of carrying or trading in stocks, bonds or other investment
} 
notes or deposits at the Fed, with the total notes and deposits created by each Reserve bank constrained by gold cover---instrument rule---requirements of $40 \%$ for notes and 35\% for deposits, with eligible paper equal to $100 \%$ of outstanding notes. Although the 1913 act's precursor, the Aldrich bill had broader discounting provisions, where any direct bank obligation, if approved by the Secretary of the Treasury was allowable, this was omitted from Federal Reserve Act. Furthermore, the Fed could only lend to member banks, not the more numerous non-member banks, except in extraordinary circumstances approved by the Board. ${ }^{18}$ Thus, by design, Fed was constrained and had potentially less flexibility in responding to a crisis than European banks. While events would prove differently, the founders of the Fed, strong believers in the real bills doctrine, may have thought that by enshrining the real bills doctrine in the Federal Reserve Act "they had created a "foolproof mechanism that would prevent panics from occurring in the first place.” (Bordo and Wheelock, 2013).

There was another crucial difference between Fed discount rate policy and those of the Bank of England and the Banque de France. Instead of maintaining a discount rate above the market rate, discount rates tended to be below. The adverse selection problem quickly arose. The Fed found that it was not simply accommodating borrowers with temporary liquidity problems; it had a substantial number of habitually weak borrowing banks; good borrowers were discouraged by the stigma they incurred. Nevertheless, the Fed's accommodation of seasonal money market demands is believed to have eliminated banking distress and panics in the 1920s (Miron 1986, White, 2013).

The first banking crisis, and in particular, the demise of the Bank of United States offers an interesting contrast to the rescues of the Comptoir d'Escompte, Baring Brothers, and LTCM in 1998. Although it was relatively smaller, runs on the bank caused both the New York Fed and the New York Superintendent of Banks to fear that its failure might spawn more runs. Pumping liquidity into this bank, the Fed provided over \$20 million (Lucia, 1985). Federal and New York authorities then sponsored a plan to merge the Bank of United States with Manufacturers Trust, Public National Bank and International Trust, with the Clearing House banks subscribing \$30 million of new capital. (Friedman and Schwartz, 1963, p. 309). Unlike the LTCM episode where

securities' was forbidden, with the exception of U.S. government securities. Discounting was only permitted for loans with a maximum term of 90 days (180 days for agricultural loans).

${ }^{18}$ A rare exercise of this power was during a local banking panic in Florida in 1929 (Carlson, Mitchener and Richardson, 2011). 
the New York Federal Reserve Bank managed the crucial meetings, the New York Superintendent was kept out of the discussions of the Clearing House banks who scuttled the plan because they disapproved of the real estate loans of the Bank of United States and because they believed that its failure would have no repercussions. The Superintendent then closed the bank and began liquidation. Friedman and Schwartz (1963, p. 311) viewed this action as a serious failure:

The withdrawal of support by the Clearing House banks from the concerted measures sponsored by the Federal Reserve Bank of New York to save the bank--measures of a kind the banking community had often taken in similar circumstances in the past—was a serious blow to the System's prestige. (1963, p. 311).

Other banks responded to news of the Bank of United States failure by borrowing \$200 million from the New York Fed, part of the rising demand for liquidity of the first banking panic.

By 1932, the president and the Congress, horrified by the steady economic decline, reacted to what they considered to be the insufficient actions of the Fed. Following President Herbert Hoover's recommendation, Congress created the Reconstruction Finance Corporation (RFC) in January 1932. The RFC was empowered to make loans to banks, other financial institutions and railroads up to $\$ 1.5$ billion to halt the rise in failures. In July 1932, the Emergency Relief and Construction Act increased the RFC’s lending capacity to \$3.3 billion. In the Glass-Steagall Act of 1932, Congress gave the Fed permission to lend on any satisfactory collateral in an emergency---including government bonds, previously excluded by real bills concerns. The act went further to provide a means to lend to banks that had insufficient eligible assets for collateral, trying to broaden the Fed's ability to provide liquidity (Friedman and Schwartz, 1963, pp. 320-1). For a longer-term market, the mortgage market, the Federal Home Loan Bank Act was passed in 1932 to provide a means for savings and loans, savings banks and insurance companies to borrow on collateral of first mortgages (Friedman and Schwartz, 1963). Although this legislation was influenced by the building and loan associations lobby (Snowden, 1995), its passage reflected the limitations on the Fed's ability to create additional lending facilities. In addition, Congress put heavy pressure on the Fed, which in April 1932 embarked on large-scale open market purchases of $\$ 1$ billion but backed off when Congress' session was over. 
Facing a huge fourth banking panic, President Franklin D. Roosevelt declared a bank holiday on March 6, 1933 and moved the U.S. off the gold standard. On March 9, Congress passed the Emergency Banking Act confirming the powers of the President to declare a bank holiday and authorizing emergency issues of Federal Reserve Bank notes. It also permitted the RFC to buy preferred stock from national and state banks (Friedman and Schwartz, 1963). The banking holiday included a “stress test.” In December 1932, there were 17,796 commercial banks, with 447 failing between the end of the year and the declaration of the holiday. To restore public confidence, examiners and auditors assessed the solvency and viability of the remaining banks, and only 11,878 were quickly opened. This activity resembles the 2009 stress test that was administered to the largest American banks, with similar positive effects on confidence. Although some national banks would be liquidated, the Comptroller of the Currency was empowered to manage national banks with impaired assets, appointing conservators who would monitor deposit inflows and outflows and oversee the reorganization of these institutions. The RFC played a major role in strengthening the weak banks by providing \$1 billion in bank capital, buying stock from 6,139 banks.

Lastly, the Emergency Banking Act sought to give the Fed more flexibility to aid banks by permitting the Fed to make advances in "exceptional and exigent circumstances" to member banks on any acceptable assets. This last provision was permanently adopted by the Banking Act of 1935 as Section 13(3) of the Federal Reserve Act, permitting Federal Reserve banks in “unusual and exigent circumstances” to discount, for any participant in a program or facility, notes approved by the Federal Reserve bank provided they are "unable to secure adequate credit accommodations from other banking institutions.” Thus, the Fed was granted the authority to take "unprecedented" actions, recognizing that it had been too constrained by law and outlook. In Table 1, we identify four “unprecedented” actions for 1930-1933 but they were not initiated by the Fed. Congress broadened the Fed's means to conduct monetary policy (4), the bank holiday provided a means to have an orderly reopening and closure of banks (5), the RFC and Federal Home Loan banks provided more aid via Treasury contributions (6), and the bank holiday led to a novel auditing ("stress test”) of the banks (7).

In earlier crises, the monetary authorities sought to limit future risk-taking; did Congress seek to do this as well in the 1930s? It has been argued that the package of New Deal reforms did much to undermine the incentives to limit risk-taking in banking, notably the elimination of 
double liability for bank stock and the introduction of deposit insurance (White, 2013). Nevertheless, Congress was aware of the moral hazard implications of deposit insurance (Calomiris and White, 1994 ), and it refused to bailout depositors in banks that failed before the creation of the FDIC and it created a fairly limited insurance program aimed at protecting smaller depositors. The expansion of deposit insurance in later years was the product of a regulatory dynamic, largely driven by lobbying of interest groups in the banking industry (White, 1998).

\section{The Penn Central Bankruptcy}

Prior to 1970, commercial paper was considered one of the safest money market instruments because only corporations with very high credit ratings issued it. It was common practice for corporations to continually roll over their commercial paper, that is, issue new commercial paper to pay off the old. Penn Central Railroad was a major issuer of commercial paper, with more than \$200 million outstanding; but by May 1970 it was on the verge of bankruptcy and it requested federal assistance from the Nixon administration. ${ }^{19}$ Despite administration support for a bailout of Penn Central, Congress decided after six weeks of debate not to pass bailout legislation. Meanwhile, the Nixon administration asked the Board of Governors of the Federal Reserve to authorize a direct loan from the Federal Reserve Bank of New York Fed to Penn Central. However, on Thursday, June 18, the New York Fed informed the Board of Governors that its staff studies indicated that Penn Central would not be able to repay the loan, and as a result the Board decided not to authorize the loan. Without this loan, Penn Central was forced to declare bankruptcy on Sunday, June 21, 1970.

Once the Federal Reserve made the decision to let Penn Central go into bankruptcy, it was concerned that Penn Central's default on its commercial paper would, as Brimmer (1989) puts it, have had a "chilling effect on the commercial paper market" (p. 6), making it impossible for other corporations to roll over their commercial paper. The Penn Central bankruptcy, then, had the potential for sending other companies into bankruptcy which, in turn, might have triggered a fullscale financial panic. To avoid this scenario, the New York Fed contacted several large money center banks on Saturday and Sunday, June 20 and 21, alerted them to the impending bankruptcy

\footnotetext{
${ }^{19}$ See Maisel (1973) and Brimmer (1989) for further discussion of the Penn Central bankruptcy episode.
} 
and encouraged them to lend to their customers who were unable to roll over their commercial paper, indicating that the discount window would be open to them to facilitate their loans. With the interest rate on discount loans below market interest rates, banks borrowed $\$ 575$ million. In addition, on June 22 the Fed decided to suspend Regulation Q ceilings on deposits of \$100,000 and over in order to keep short-term interest rates from rising, and the formal vote was taken the next day to allow the FDIC and the Federal Home Loan Bank Board to take parallel action. The net result was that the Federal Reserve provided liquidity to ensure the continued smooth functioning of the commercial paper market.

The rationale for the Fed's action was that an unprecedented bankruptcy in the commercial paper market would lead lenders to pull out because they would no longer be confident that they could accurately screen borrowers, which was reflected in credit markets by a widening of credit spreads. After these actions, credit spreads came back down and commercial paper rates fell sharply, indicating a rapid recovery in the commercial paper market. The financial disruption from the Penn Central bankruptcy therefore turned out to be small and the recession which started shortly before the Penn Central bankrupty occurred was mild.

This policy action clearly was unprecedented and a violation of the Bagehot rule because lending was done at below market interest rates. However, these below market rates and the Fed's commitment to provide funds to keep that market functioning had the advantage that it made it profitable for banks to lend directly to a market where credit had dried up. This approach enabled the Fed to direct credit to nonfinancial firms that it was not monitoring, having the banks lend to them instead. These banks then had the incentive to monitor these firms to prevent them from taking on excessive risk because the banks would be on the hook if the loans went sour. The Fed thus used the banks as delegated monitors to ameliorate potential moral hazard that could lead to excessive risk taking. This action avoided the necessity for the Fed to lend to firms that it did not supervise and had little expertise in monitoring; and it is treated in Table 1 as a non-Bagehot liquidity facility even though the action was indirect. The Federal Reserve's actions did have elements of discretion, but because the Fed used delegated monitors to constrain moral hazard risk, these actions can be characterized as constrained discretion. 


\section{Continental Illinois 1984}

In 1984, Continental Illinois, the seventh largest bank in the United States, experienced a bank run when uninsured depositors became convinced that it was insolvent. In its drive to become the nation's largest commercial and industrial lender, Continental Illinois became imperiled by large oil and gas loans that it had purchased. Rumors of Continental Illinois' problems started runs by large uninsured depositors in early May 1984, leading the bank to borrow heavily from the Federal Reserve Bank of Chicago. Its borrowings from the Fed reached $\$ 3.5$ billion by May 11. Continental Illinois then sought an additional \$4.5 billion from a group of banks, collateralized by $\$ 17$ of assets on deposit at the Fed (Wall and Peterson, 1990).

The size of the institution and its ties to other banks led by the Federal Reserve and the FDIC to conclude that intervention was necessary to prevent a general banking panic. A bailout plan was put forward on May 17, where the FDIC gave the bank \$1.5 billion in new capital and a group of banks injected $\$ 500$ million. A group of 28 banks provided a $\$ 5.5$ billion line of credit, with the Fed supplying additional liquidity. Crucially, the FDIC promised 100 percent protection to all creditors of the bank, thus halting the run (FDIC, 1997).

In the next two months, regulators sought a merger partner for Continental but failed. For the final resolution, in July 1984, the FDIC agreed to buy \$4.5 billion of bad loans from the bank, with a $\$ 1$ billion charge-off by the bank and a capital infusion of \$1 billion from the FDIC. The FDIC assumed Continental's \$3.5 billion debt to the Federal Reserve Bank of Chicago in exchange for a transfer to the FDIC of assets from Continental Illinois, which had a book value of $\$ 4.5$ billion and an adjusted book value of $\$ 3.5$ billion. The FDIC also received a package of nonperforming, classified or poor quality loans with a book value of $\$ 3$ billion. These were valued at $\$ 2$ billion, with the $\$ 1$ billion taken by the bank as a charge against its capital. Furthermore, Continental Illinois gave the FDIC a note for $\$ 1.5$ billion to be repaid within three years by transferring loans with a book value of $\$ 1.5$ billion to the agency. To offset the $\$ 1$ billion charge to capital, the FDIC purchased preferred stock issues in the bank holding company that were delivered to the bank as equity. The top management and board of directors were removed (FDIC, 1998). In Table 1, intervention for Continental Illinois is treated as part of an orderly rescue or liquidation, in Column 5. 
The Continental Illinois episode provides an interesting contrast to pre-Great Depression interventions by central banks. In the earlier period, bank failures would have been handled either by the courts, as in Britain or France, or by specialized agency like the Comptroller of the Currency in the United States. The courts and the OCC had no option but to liquidate banks and they had no funds to assist with a failed bank's continued operation; but a central bank might intervene, having the resources to provide for a more orderly resolution, as in the case of the Comptoir d'Escompte and Barings. The creation of the FDIC reduced the need for the Fed to take this action, but the size of the FDIC's fund limited the agency and a bank might still need liquidity from the Fed, as in the case of Continental Illinois.

However, there was a marked difference between the actions of the monetary authorities in 1984 and the Banque de France in 1889 and the Bank of England in 1890. Unlike earlier European bank failures or even the failures during the Great Depression, the FDIC pre-emptively stepped forward to insure all creditors, instead of cooperating with the Fed to ensure that only insured depositors were made whole. This action was clearly discretionary and was contrary to the need to mitigate the effect of moral hazard arising from its intervention. Indeed, the FDIC's actions established that large banks were "too big to fail," which was confirmed by the Comptroller of the Currency at a Congressional hearing shortly after the Continental Illinois bailout. This too-big-to-fail policy encouraged large banks to take on excessive risks because their creditors knew that they would be protected from any losses and so no longer needed to monitor the bank's risky activities as closely. The too-big-to-fail policy then played a role in excessive risk taking that led to the banking crisis of the late 1980s and early 1990s, as well as the banking crisis that accompanied the global financial crisis from 2007 to 2009 (Stern and Feldman, 2004).

\section{Stock Market Crash of 1987}

The biggest danger to the economy from the stock market crash of 1987 did not come from the decline in wealth resulting from the crash itself, but rather from the threat to the clearing and settlement system in the stock and futures markets. ${ }^{20}$ From the peak on August 25, 1987 until

\footnotetext{
${ }^{20}$ See the Wall Street Journal (1987) and Brimmer (1989) for a description of the events surrounding the stock market crash.
} 
October 16, just prior to the crash, the Dow Jones Industrial Average had declined 17.5\%. On Monday, October 19, the market fell by $22.6 \%$ on a record volume of 604 million shares. Although October 19, 1987, dubbed "Black Monday", was the largest one-day percentage decline in stock prices to date, it was the next day. Tuesday, October 20,1987, that imperiled financial markets. To keep the stock market and the related index futures market functioning in an orderly fashion, brokers needed to extend massive credits to their customers as margin calls were made. The magnitude of the problem is illustrated by the fact that just two brokerage firms, Kidder, Peabody and Goldman, Sachs, had advanced \$1.5 billion in response to margin calls on their customers by noon of October 20. Brokerage firms and specialists were in dire need of additional funds to finance their activities. However, understandably enough, banks had grown nervous about the financial health of securities firms and were reluctant to lend.

Upon learning of the plight of the securities industry, Alan Greenspan and E. Gerald Corrigan, the president of the New York Federal Reserve Bank and the Fed official most closely in touch with Wall Street, began to fear a breakdown in the clearing and settlement systems and the collapse of securities firms. To prevent this from occurring, Greenspan announced, before the market opened on Tuesday, October 20, the Federal Reserve System's "readiness to serve as a source of liquidity to support the economic and financial system." In addition to this extraordinary announcement, the Fed encouraged key money center banks to lend freely to their brokerage firm customers, and, as in the Penn Central bankruptcy episode, made it clear that it would provide discount loans to banks so that they could make these loans. However, as in the Penn Central episode, the banks making the loans would face losses if the firms they lent to ran into difficulties after the crisis was over, so the Federal Reserve was again using the banks as delegated monitors to reduce moral hazard risk taking. The Federal Reserve's actions can thus be thought of as being discretionary, but nonetheless representing constrained discretion because they addressed moral hazard risk. Given this backstop, banks increased their loans to brokers and to individuals to purchase or hold securities by $\$ 7.7$ billion. As a result, the markets were not disrupted and a market rally ensued raising the DJIA by over 100 points (over 5\%) on October 22. This action by the Fed was reminiscent of the actions taken by the Federal Reserve Bank of New York during the October 1929 panic period in which it provided liquidity to enable money center banks to take over call loans which had been called by others. 
Credit spreads did rise in the immediate aftermath of the crash; the junk bond-Treasury spread jumped by 130 basis points the week of the crash and by another 60 basis points over the next two weeks. However, within two months, this credit spread returned to pre-crash levels (Mishkin, 1991). The failure to enter a recession after the stock market crash, despite many forecasters predictions along these lines, is consistent with the view that the Fed's actions were effective in calming the credit markets. In Table 1, we treat 1987 as we did 1929, as having unusual monetary easing

\section{LTCM 1998}

The rise and collapse of Long-Term Capital Management in 1999 demonstrated for the first time the potential of individual non-banking intermediaries-particularly hedge funds---to spawn a general financial crisis that required the Federal Reserve to intervene, though not to make use of its broad Federal Reserve Act 13(3) powers.

Organized as a limit liability partnership for high wealth and institutional investors, like most hedge funds, LTCM's purpose was to engage in speculative strategies virtually free of regulation and oversight. Starting with a capital of \$1.3 billion in 1994, LTCM grew quickly to $\$ 7$ billion in 1997 when the management concluded that there were limits to its strategy and returned \$2.7 billion of equity to investors, leaving the firm with \$4.8 billion in early 1998 . LTCM sought to reap extraordinary returns by "market-neutral arbitrage" (Edwards, 1999; Lowenstein, 2000). Using derivative contracts it took long positions in bonds that it believed to be overvalued, and short positions in bonds it considered to be undervalued. In early post-Asian crisis in 1998, this strategy focused on the large spread between high risk bonds and low risk bonds that they believed to be a temporary and soon-to-be reversed phenomenon. Certain of their forecast, LTCM borrowed at least \$125 billion from banks and entered into derivative contracts with a notional value in excess of $\$ 1$ trillion---creating the potential for very large gains or losses if spreads narrowed or widened. This risk was amplified by the fact that LTCM held large quantities of illiquid securities in its portfolio.

Lenders and counterparties were willing to accept LTCM's huge exposure because of the outsize reputation of its partners and because they were largely unaware of the magnitude of the risks it had incurred thanks to LTCM's unchallenged secretiveness. Disaster hit when Russia 
defaulted on its bonds and spreads surged. Combined with a rush to liquidity and quality, LTCM sustained huge losses that nearly wiped out its equity by September. If LTCM had dumped its portfolio, asset values might have collapsed, threatening many financial institutions, owing to their position as counterparties to LTCM's swaps. Desperate for capital, LTCM sought to find one or more white knights to provide new equity but failed. The Federal Reserve Board showed no signs of providing liquidity; and on September 16, Greenspan ruled out a reduction in interest rates and stated that "Hedge funds are strongly regulated by those who lend the money." (Quoted in Lowenstein, 2000, p. 178). However, with the risk of a general market meltdown, the president of the Federal Reserve Bank of New York, William McDonough convened a meeting on September 22, 1998 of all major financial institutions involved with LTCM. After considerable wrangling, on September 28, a 16 member consortium provided \$3.6 billion in capital in exchange for 90\% of LTCM's equity---a lifeboat for LTCM. Although the Fed did not provide any equity or loans, supplying only "office space” and "some guidance” (Edwards, 1999) its intervention with a “creditor rescue” helped LTCM to avoid a formal default, a contrast to the failure of the New York Superintendent of Banks intervention on behalf of the Bank of United States in 1930.

A key problem in the crisis were LTCM's vast derivative contracts, which had no automatic stay if LTCM defaulted and became bankrupt, leaving counterparties to liquidate any of LTCM's assets in their control. Thus there was a potential for a fire sale that would have reduced the value of LTCM and potentially other institutions with similar assets. In effect, the Fed indirectly ensured that there was an orderly resolution of LTCM.

Immediately after the formation of the lifeboat for LTCM, the Fed cut the Fed funds target rate on September 29 from 5.5\% to 5.3\%. This cut was in direct response to the crisis' eruption as the U.S.; and, as during the recent financial crisis, it was done while the economy was still in the midst of a boom that had begun in March 1991 and would not peak until March 2001 (NBER Business Cycles, www.nber.org). Yet this cut was insufficient; and with swap spreads continuing to widen and LTCM continuing to weaken, other financial institutions with similar exposure, took large hits against their capital. Only when the Fed cut rates for a second time and third time on October 15 and November 17 when the Fed funds rate reached 4.8\% did spreads narrow and calm return to the markets (Lowenstein, 2000). In Table 1, the exceptional 
actions of the Fed include the unusual easing of monetary policy and assisting with an orderly resolution of a firm on the brink of insolvency.

Once the shock dissipated, pursuing a contingent rule would have indicated that the Federal Reserve would take away the federal funds rate cuts. This was not done and we consider this to be one of the serious mistakes made by the Federal Reserve under Greenspan. Not only did inflation subsequently rise, going above $2 \%$, a level that is considered to be an appropriate objective currently by the Federal Reserve and other central banks, but these monetary actions indicated that the Federal Reserve would react asymmetrically to shocks, lowering interest rates in the event of a financial disruption, but not raising them upon reversal of the adverse shock. Federal Reserve monetary policy actions during this period were therefore purely discretionary because they helped contribute to the belief in the "Greenspan put", a form of moral hazard in which financial institutions expect monetary policy to help them recover from bad investments (e.g., see Tirole and Farhi, 2009, and Keister, 2010). The failure of the Greenspan put to constrain moral hazard is one factor that has been cited as playing a role in the excessive risk taking that helped lead to the global financial crisis from 2007 to 2009.

\section{Overview of the Historical Experience}

It is common for economists to recommend that central banks adopt an instrument rule, like Bagehot's rule, for managing financial crises. By signaling a commitment to this instrument rule, central banks can limit moral hazard and discourage risk-taking that can pave the way for the next financial crisis. While central banks have had over two centuries to consider this advice, put forward by Thornton in 1802 and then forcefully argued by Bagehot in 1873, they typically don't follow it.

The central banks in our historical survey---the Bank of England, the Banque de France and the Federal Reserve---initially attempted to follow versions of Bagehot's rule. In 1866, to confront the panic begun by the collapse of Overend-Gurney, the Bank of England lent freely at a high rate of interest on only good collateral, after securing permission from the Treasury to violate the currency-issue/gold reserve instrument rule. Solvent institutions were given the liquidity to ride out the crisis and the economy absorbed the heavy shock of the failing banks. Yet, when Baring Brothers collapsed in 1890, neither the Bank of England nor the leading 
bankers were willing to strictly apply Bagehot's rule, the discount rate was not jacked up and swaps were arranged with other central banks to obtain liquidity. For Baring Brothers, a lifeboat was formed to ensure an orderly liquidation of the bank, with the Bank of England providing liquidity as needed for the rest of the financial system, according to Bagehot's precepts. Losses from this failure were not born by the taxpayer or the Bank of England but primarily by the partners of the failing bank, especially the Barings family. The recognition of the Bank's success gave credibility to its contingent rule for combining price and financial stability.

This same shift is observed for the Banque de France. In 1882, when a large bank, Union Generale failed, its demise bankrupted the stock exchange in Lyon and threatened to do the same for the Paris Bourse. The Banque de France could not assist the Paris exchange directly because it lacked the exact collateral prescribed by the Banque's statutes. However, a lifeboat for the Bourse was provided via a group of banks that had the correct collateral and intermediated the loan. The exchange survived, though hobbled under its debt for the next several years; and the crisis set off a severe recession that had a slow recovery. This experience seems to have altered the Banque de France's response to the imminent failure of one of the top banks in 1889, the Comptoir d'Escompte. This time the Banque did not hesitate to lend to the Comptoir on questionable assets and formed a lifeboat operation before a panic took hold, providing additional credit with no higher interest rates to other financial institutions seeking liquidity but imposing harsh penalties for those involved in precipitating the crisis. This prompt pre-emptive strike may well have informed the Bank of England's response the next year and influenced the Banque's decision to set up special lending facilities to cope with the crisis 1907.

The trajectory of the Fed was similar but it was Congress that initiated the shift to contingent rules for addressing financial crises not the Fed. The panic of 1907, where a number of extraordinary measures were taken by the Treasury and the New York Clearing House set the stage for the creation of the Federal Reserve System. As a new institution, the Fed took its mandate---with its limitations---very seriously, However, when the first major crisis, the Stock Market Crash of 1929, hit, the Federal Reserve Bank of New York, anxious to contain the crisis, exceeded its authority, temporarily breeching the instrument-rule procedures designed to ensure price stability by expanding open market operations. Encouraging banks to borrow at the discount window without stigma so that they could lend to troubled brokers kept the crisis contained. The correctness of this action is reflected by the fact that very similar action was 
taken by the Federal Reserve Board in 1987 in response to the stock market crash of that year. The difference between 1987 and 1929 was that in 1929, the Board did not initiate or approve of this bold action and censured the New York Fed. The Fed then returned to a very strict interpretation of its mandate, effectively dismissing the need to address the mounting bank failures and panics of 1930-1933. If banks needed liquidity, the discount window was open; but since there was no line at the window, expansionary measures were assumed to be unnecessary. As the Fed was unwilling to initiate flexibility, Congress responded with new legislation to expand the Fed's ability to lend and intervene, most notably giving the Fed discretionary authority to provide credit via Section 13(3). Significantly, no morally hazardous bailout was seriously considered for the depositors or shareholders of banks that failed during 1930-1933.

The bankruptcy of Penn Central in 1970 seems to have followed this playbook. Although subject to significant political pressure to help the railroad, the Fed refused to provide assistance. But concerned that Penn Central's bankruptcy would hammer the commercial paper market, the Fed signaled to banks that they could readily borrow from the discount window with no stigma, if their customers could not roll over their commercial paper and needed short-term credits. Penn Central received no favors and the rest of the market was assured access to short-term lending.

The necessary drastic measures needed to constrain moral hazard when there is a preemptive central bank intervention are evident in these late nineteenth and early to mid-twentieth century cases. Beginning in the late twentieth century, pre-emptive discretionary interventions increased but the safety net for bank stakeholders was expanded, creating growing incentives for risk-taking. The rising tide of bank and savings and loan failures in the late 1970s and early 1980s appears to have altered the earlier strict policy.

The failure and bailout of Continental Illinois in 1984 represented a key shift in policy, effectively inaugurating the Too-Big-To-Fail doctrine. Runs by uninsured depositors of Continental Illinois persuaded regulators that its failure could produce a full-scale banking panic. With the Fed supplying liquidity and the FDIC supplying capital, Continental Illinois was bailed out, providing 100 percent insurance for creditors and bond holders. The contrast in the penalties assessed against stakeholders in the earlier crises surveyed here is striking; especially since the authorities actions in 1984 were recognized as creating substantial moral hazard. Even when the Fed has appeared to avoid intervention, as in the case of LTCM, by holding meetings 
to induce banks to form a lifeboat to rescue the hedge fund; managers of LTCM and other involved financial institutions continued in the business, though they sustained huge losses,. In addition, the widening of interest rate and swap spreads was met by the Fed's lowering of interest rates. While this was effective in narrowing spreads, interest rates were not raised afterwards and Greenspan's promise to prevent crises became the "Greenspan put." The discretionary violation of the target rule thus did not appear to be temporary and the resolve to contain moral hazard was sharply diminished.

This overview of the historical episodes suggests that they can be classified into three categories. The first category includes episodes in which the central bank adhered too strictly to instrument rules and thus took no pre-emptive actions to deal with financial crises: the U.S. 1930-33 period is the classic example. The Federal Reserve's inactivity during this period has been widely viewed as contributing to a sharp decline in U.S. and global output.

The second category includes episodes in which central banks deviated from the currency-issue/gold reserve rules, but were clearly committed to take actions to reduce moral hazard: these include the U.K in 1890, France in 1889, and the U.S. in 1929, 1970 and 1987. We would argue that these central bank deviations from instrument rules were highly successful in limiting the damage from the financial disruption to the economy, and yet were conducted so that moral hazard was limited and therefore did not make the financial system more vulnerable. The third category includes episodes where the central bank and the government engaged in discretionary actions where efforts to limit moral hazard were weak: these include the Continental Illinois episode in 1984 and monetary policy easing taken in 1998 in the aftermath of the LTCM crisis. Although these discretionary actions limited the damage from the financial disruption, they should not be viewed as successful interventions because they created moral hazard incentives for financial institutions to take on excessive risk that set the stage for later financial crises. 


\section{Conclusions}

The historical experience provides several lessons.

- First, the "unprecedented" actions of the Federal Reserve during the global financial crisis were in line with what central banks, including the Federal Reserve, did in previous episodes of financial disturbances. "Unprecedented” actions have been a part of a central bank's arsenal since the nineteenth century.

- Second, “unprecedented” actions in which instrument rules were temporarily abandoned, but discretion was constrained, were frequently successful in stabilizing the financial system and the aggregate economy. Indeed, unwillingness to deviate from instrument rules, as occurred during the 1930-1933 episode led to a disastrous outcome. This episode provides an important rationale for the Federal Reserve adoption of “unprecedented” actions during the recent global financial crisis.

- Third, the historical experience indicates that discretionary deviations from Bagehot's rule can promote financial instability if steps are taken to mitigate the moral hazard that these actions encourage. The “unprecedented" actions associated with Continental Illinois in 1984 and LTCM in 1998 increased morally hazardous risk-taking by financial institutions and were an important factor that led to the banking crisis of the late 1980s and early 1990s and the global financial crisis of 2007-2009.

The historical experience therefore suggests that the concerns for designing a central bank's mandate should not focus on whether a central bank should strictly follow instrument rules. Rather, the concerns for designing a central bank's mandate should focus on how an appropriate target rule or contingent rule can be developed to constrain discretion and mitigate moral hazard. The Federal Reserve’s “unprecedented” actions during the global financial crisis should thus be judged not on whether they should have been pursued but rather on whether they were accompanied by adequate measures to maintain a target rule and constrain moral hazard. 


\section{Bibliography}

Acharya, Viral and Amit Seru, 2013, “What Do Macro-Prudential Stress Tests Resolve: Asymmetric Information, Debt Overhang or Regulatory Uncertainty?” New York University, manuscript

Bagehot, W., 1873. Lombard Street: A Description of the Money Market. H.S. King, London.

Bernanke, Ben S., Thomas Laubach, Frederic S. Mishkin, and Adam Posen. 1999. Inflation Targeting: Lessons from the International Experience (Princeton University Press: Princeton, 1999).

Bernanke, Ben S. and Frederic S. Mishkin, 1997. "Inflation Targeting: A New Framework for Monetary Policy?" (with Ben Bernanke) Journal of Economic Perspectives 11, 2 (Spring): 97-116.

Bignon, V., Flandreau, M., Ugolini, S., 2012. Bagehot for beginners: the making of lender-oflast resort operations in the mid-nineteenth century. Economic History Review 65, 2, 580-608.

Board of Governors of the Federal Reserve System,. 2009. “The Supervisory Capital Assessment Program: Design and Implementation,” April 24, http://www.federalreserve.gov/bankinforeg/bcreg20090424a1.pdf.

Bordo, Michael D. 1986. "Financial Crises, Banking Crises, Stock Market Crashes and the Money Supply: Some International Evidence, in Forrest Capie and Geffrey Wood, eds, Financial Crises and the World Banking System (London: MacMillan).

Bordo, M.D, 1990. The Lender of Last Resort: Alternative Views and Historical Experience, Federal Reserve Bank of Richmond Economic Review, (January/February), 18-29.

Bordo, M.D and F. E. Kydland, “The Gold Standard As a Rule: An Essay in Exploration,” Exporations in Economic History 32, (1995) pp.423-464.

Bordo, M.D. and E. N. White, "British and French Finance during the Napoleonic Wars," in M.D. Bordo and F. Capie, eds., Monetary Regimes in Transition (Cambridge: Cambridge University Press, 1994) pp. 241-273.

Bordo, M. D. and D. C. Wheelock, in "The Promise and Performance of the Federal Reserve as Lender of Last Resort, 1914-1933,” in M. D. Bordo and W. Roberds, The Origins, History and Future of the Federal Reserve: A Return to Jekyll Island (Cambridge: Cambridge University Press, 2013), pp. 59-98.

Brimmer, Andrew F., 1989 "Distinguished Lecture on Economics in Government: Central Banking and Systemic Risks in Capital Markets," Journal of Economic Perspectives 3 (Spring), pp. 3-16. 
Calvo, G.A. (1978), “On the Time Consistency of Optimal Policy in a Monetary Economy”, Econometrica, Vol. 46, No 6, pp. 1411-1428.

Capie, Forrest and Ghila Rodrik-Bali, “Concentration in British Banking, 1870-1920,” Business History (November, 1982) pp. 280-292

Calomiris, C.W. and E. N.White, "The Origins of Federal Deposit Insurance,” in C. Goldin and G. D. Libecap, eds., The Regulated Economy: A Historical Approach to Political Economy (Cambridge: Cambridge University Press, 1994), 145-188.

Carlson, M, Mitchener, K.J. and Richardson, G., "Arresting banking panics: Federal Reserve liquidity provision and the forgotten panic of 1929," Journal of Political Economy 119:5 (2011), pp. 889-924.

Clapham, J., 1945. The Bank of England: A History. Vol. II, The Macmillan Company, New York.

Coy, Peter, “Volcker Shuns the Blame Game,” Business Week, April 10, 2008.

Dutton, John, “The Bank of England the Rules of the Game under the International Gold Standard: New Evidence,” in Michael D. Bordo and Anna J. Schwartz, eds., A Retrospective on the Classical Gold Standard, 1821-1931 (Chicago: University of Chicago Press, 1984), pp. 173202.

Edwards, Franklin R. "Hedge Funds and the Collapse of Long-Term Capital Management," Journal of Economic Perspectives 13: 2 (Spring 1999), pp. 189-210.

Eschweiler, Bernhard, and Michael D. Bordo, "Rules, Discretion, and Central Bank Independence: the German Experience, 1880-1989,” in Pierre, L. Siklos, Varieties of Monetary

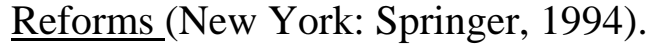

Federal Deposit Insurance Corporation, History of the Eighties---Lessons for the Future (FDIC: Washington, D.C., 1997).

Federal Deposit Insurance Corporation, Managing the Crisis: The FDIC and RTC Experience, 1980-1994 (FDIC: Washington, D.C., 1998).

Federal Deposit Insurance Corporation, 2008, “FDIC Announces Plan to Free Up Bank Liquidity,” Press Release, October 14, http://www.fdic.gov/news/news/press/2008/pr08100.html.

Flandreau, M. and S. Ugolini, “The Crisis of 1866,” (Geneva: Graduate Institute of International and Development Studies, working paper, No. 10, 2014).

Friedman, Milton, Anna J. Schwartz, A Monetary History of the United States, 1867-1960 (Princeton: Princeton University Press, 1963). 
Giannini, Curzio, The Age of Central Banks (Cheltenham: Edward Elgar, 2004).

Giovannini, A., "'Rules of the Game’ During the International Gold Standard, England and Germany,” Journal of International Money and Finance 5 (1986), pp. 467-483.

Grossman, H.I. and J.B. van Huyck, "Sovereign Debt as a Contingent Claim: Excusable Default, Repudiation and Reputation,” American Economic Review 78 (1988), pp. 1888-1097.

Grossman, R. S., Unsettled Account: The Evolution of Banking in the Industrialized World Since 1800 (Princeton: Princeton University Press, 2010).

Grossman, R.S. and H. Rockoff, "Fight the Last War: Economists on the Lender of Last Resort," Of the Uses of Central Banks: Lessons of History, Norges Bank Conference June 5-6, 2014.

Hautcoeur, P.-C. , A. Riva, and E. N. White, "Floating a Lifeboat: the Banque de France and the Crisis of 1889,” Journal of Monetary Economics, June? July? 2014

Hoshi, Takeo and Anil Kashyap, 2010, "Will the U.S. Bank Recapitalization Succeed? Eight Lessons from Japan” (Joint with Anil Kashyap), Journal of Financial Economics, 97, 398-417, September.

Humphrey, T., 1975. Lender of Last Resort: The Concept in History. Federal Reserve Bank of Richmond Economic Review. (March/April), 75, 8-16.

Keister, T. 2010, “Bailouts and Financial Fragility”, Federal Reserve Bank of New York unpublished manuscript.

Kydland, F.E. and Prescott, E.C. 1977. "Rules Rather Than Discretion: The Inconsistency of Optimal Plans”, Journal of Political Economy, Vol. 85, June, pp. 473-492.

Lowenstein, Roger, When Genius Failed : The Rise and Fall of Long-Term Capital Management (New York : Random House, 2000).

Lucia, J. L., "The Failure of the Bank of United States: A Reappraisal," Explorations in Economic History 22 (1985), pp. 402-416.

Madigan, B.F., "Bagehot's Dictum in Practice: Formulating and Implementing Policies to Combat the Financial Crisis,” Jackson Hole, Wyoming Symposium, Federal Reserve Bank of Kansas City (August 21, 2009),

Maisel, Sherman J., Managing the Dollar (New York: Norton 1973).

Meltzer, A.H., A History of the Federal Reserve Volume 1, 1913-1951 (Chicago: University of Chicago Press, 2003).

Meltzer, A. H., “Reflections on the Financial Crisis,” Cato Journal 29: 1 (2009), pp. 45-51 
Miron, J., "Financial Panics, the Seasonality of the Interest Rate and the Founding of the Fed, American Economic Review 76 (1986), pp. 125-140.

Mishkin, Frederic S., "Over the Cliff: From the Subprime to the Global Financial Crisis," Journal of Economic Perspectives, Vol. 25, No. 1 (Winter 2011), pp. 49-70.

Mishkin, Frederic S. 1991. “Asymmetric Information and Financial Crises: A Historical Perspective," in R. Glenn Hubbard, ed., Financial Markets and Financial Crises (University of Chicago Press: Chicago, 1991): 69-108.

Mishkin, Frederic S. 2011. "Monetary Policy Strategy: Lessons From the Crisis” in Marek Jarocinski, Frank Smets and Christian Thimann, eds. Monetary Policy Revisited: Lessons from the Crisis, Sixth ECB Central Banking Conference (European Central Bank: Frankfurt, 2011), pp. 67-118.

Mishkin, Frederic S. and Klaus Schmidt-Hebbel, "One Decade of Inflation Targeting in the World: What Do We Know and What Do We Need to Know?” in N. Loayza and R. Soto, Inflation Targeting: Design, Performance, Challenges (Santiago: Central Bank of Chile, 2002), pp. 171-219.

Moen, J.R. and E. W. Tallman, “Clearinghouse Membership and Deposit Contraction During the Panic of 1907,” Journal of Economic History 60: 1 (2000), pp. 145-163.

NBER, Business Cycles, www.nber.org.

Odell, Kerry and Marc Weidenmier, "Real Shock, Monetary Aftershock: the 1906 San Francisco Earthquake and the Panic of 1907,” Journal of Economic History 64:4 (M2004), pp. 1002-1027.

Pippenger, J., "Bank of England Operations1893-1913, in Michael D. Bordo and Anna J. Schwartz, eds., A Retrospective on the Classical Gold Standard 1821-1931 (Chicago: Chicago University Press, 1984), pp. 233-276.

Rodgers, Mary Tone and James E. Payne, "How the Bank of France Changed U.S. Equity Expectations and Ended the Panic of 1907,” Journal of Economic History, 74:2 (June 2014), pp. 420-448.

Romer, C.D., “The Nation in Depression, Journal of Economic Perspectives 7:2 (Spring 1993); 7:2, 19-39.

Snowden, K. A., "Mortgage Securitization in the United States: Twentieth Century Developments in Historical Perspective,” in M. D. Bordo and R. Sylla, Anglo-American Financial Systems: Institutions and Markets in the Twentieth Century, (New York: Irwin, 1995), pp. 261-298. 
Stern, G.H. and Ron J. Feldman, Too Big to Fail: The Hazards of Bank Bailouts (Washington, D.C.: The Brookings Institution, 2004).

Taylor, John, B. 2009. Getting Off Track: How Government Actions and Interventions, Caused, Prolonged and Worsened the Financial Crisis (Stanford, CA: Hoover Institution Press).

Taylor, John, B. and John Williams, 2009. “A Black Swan in the Money Market,” American Economic Journal: Macroeconomics 1(1): 58-83.

Thornton, H. 1802. An Enquiry into the Nature and Effects of the Paper Credit of Great Britain., Hayek, F. (Ed.), August M. Kelley, Fairfield.

Tirole, J. and Farhi, E. 2009, “Collective Moral Hazard, Maturity Mismatch and Systemic Bailouts”, NBER Working Paper Series, No 15138.

Wall, L.D. and D. R. Petersen, "The effect of Continental Illinois' failure on the financial performance of other banks,” Journal of Monetary Economics 26:1 (1990), pp. 77-99.

Wall Street Journal, 1987. "Terrible Tuesday: How the Stock Market Almost Disintegrated a Day After the Crash, November 20, 1987.

White, E. N.,’The Legacy of Deposit Insurance: The Growth, Spread, and Cost of Insuring Financial Intermediaries,” in M.D. Bordo, C. Goldin and E.N. White, eds., The Defining Moment: The Great Depression and the American Economy in the Twentieth Century (Cambridge: Cambridge University Press, 1998), 87-124.

White, E. N., 2007. The Crash of 1882 and the Bailout of the Paris Bourse. Cliometrica 1, 2 (July), 115-144.

White, E.N., 2013, "To Establish More Effective Supervision: How the Birth of the Fed Altered Bank Supervision,” in M.D. Bordo and W. Roberds, A Return to Jekyll Island: The Origins, History and Future of the Federal Reserve (Cambridge: Cambridge University Press, 2013), pp. 7-55.

Wheelock, David C., The Strategy and Consistency of Federal Reserve Monetary Policy, 19241933 (Cambridge: Cambridge University Press, 1991).

Wicker, Elmus R., Federal Reserve Monetary Policy, 1917-1933 (New York: Random House, 1966).

Wood, John H., A History of Central Banking in Great Britain and the United States (Cambridge: Cambridge University Press, 2005). 